\title{
Age- and size-dependent mating performance and fertility in a pelagic copepod, Temora longicornis
}

\author{
Mie Hylstofte Sichlau*, Thomas Kiørboe
}

National Institute of Aquatic Resources, Technical University of Denmark, Kavalergården, 2920 Charlottenlund, Denmark

\begin{abstract}
In many species, size and age can be strong determinants of the reproductive success for both sexes. We examined age- and size-dependent reproductive performance (egg and sperm production, mating success) in a pelagic copepod, Temora longicornis. Compared with smaller males, larger males produced larger spermatophores containing more spermatozoa and fertilized a larger fraction of available females. Females mating with large males produced more offspring than those mating with small males. Similarly, large females had higher egg production rates as well as a higher lifetime egg production than did small females. Ageing effects were evident in this species: mortality rate increased and fertility decreased rapidly with age. The average adult longevity under optimal laboratory conditions was $30 \mathrm{~d}$ in both males and females, but females produced eggs for only $18 \mathrm{~d}$, and males could fertilize females for only about $8 \mathrm{~d}$ after they matured. The strong size- and age-dependent fertility observed in this species is conducive to the development of sexual selection via mate choice for young and large partners, as has been shown in another copepod species.
\end{abstract}

KEY WORDS: Spermatophore $\cdot$ Spermatozoa $\cdot$ Egg production $\cdot$ Ageing $\cdot$ Mortality rate $\cdot$ DAPI $\cdot$ Temora longicornis

Resale or republication not permitted without written consent of the publisher

\section{INTRODUCTION}

Reproduction and mate choice are important determinants of the evolution and life history of all organisms (reviewed in Andersson 1994), and in many species both depend on the body size and age of the individual. Generally, larger individuals of a species produce more gametes and their mating performance typically declines with age (MacDiarmid \& Butler 1999, Radwan et al. 2005, Lehmann \& Lehmann 2009, Gasparini et al. 2010, Judge et al. 2010). Here we examined how reproductive performance and mortality depended on size and age in a pelagic copepod, Temora longicornis.

Numerous studies have shown that the variation in copepod fecundity is related to changes in food quantity and quality (Jonasdottir et al. 1995, 2009, Dam \& Lopes 2003, Koski et al. 2006), salinity (Holste et al. 2009) and temperature (Ban 1994, Holste et al. 2009), but few have tested the effect of ageing on fecundity (Carlotti et al. 1997, Rodriguez-Grana et al. 2010, Ceballos \& Kiørboe 2011). Ageing is the progressive decline in biological functions with advancing age and the accumulation of change in an organism over time. Ageing can have a profound negative effect on the individual fitness of some pelagic copepod species, e.g. on feeding rates, oxidative damage, egg production rate and egg hatching success (Carlotti et al. 1997, Rodriguez-Grana et al. 2010, Ceballos \& Kiørboe 2011). Male ageing can have evolutionary and ecological consequences on gamete performance and fitness (see Pizzari et al. 2008). The quality of the genes that a male passes to his progeny may change with his age (Hansen \& Price 1995) owing to the accumulation of deleterious mutations in the germline (Risch et al. 1987, Drost \& Lee 1995, 
Hurst \& Ellegren 1998, Bartosch-Härlid et al. 2003, Glaser \& Jabs 2004). Ageing can also affect the quantity of sperm because an increasing proportion of germ cells bear mutations as age increases, and such cells are destroyed by genetic self-guarding processes (Radwan 2003). Older males, however, have passed more episodes of selection and thus may be better adapted than the average male (Manning 1985). The breeding value (i.e. offspring performance) of older males will thus depend on specific life history characteristics (Kokko 1998, Beck \& Powell 2000) and on the number of divisions a male germline undergoes after it reaches maturity (Radwan 2003). Therefore, it is not surprising that female preferences with respect to the age of the male differ among species (reviewed in Brooks \& Kemp 2001). Little is known about the reproductive performance of male copepods, and less about the age dependency of male reproduction.

Adult body length of many copepods may vary substantially with both temperature and food availability by up to a factor of 2 within a species (Berggreen et al. 1988, Dam \& Peterson 1991, Arendt et al. 2005). Female fecundity typically increases with body size in both insects and crustaceans, including copepods (Honêk 1993, Aquiloni \& Gherardi 2008, Ceballos \& Kiørboe 2010). Spermatophore size and sperm quantity is similarly correlated with male size in insects and a single copulation by a small mature male may not provide enough sperm to fertilize all the eggs produced by a large female (McLain et al. 1990, Bissoondath \& Wiklund 1996). Ceballos \& Kiørboe (2010) showed that large males of Acartia tonsa produce larger spermatophores than do small males, and that the production of offspring in the female increases with the size of the spermatophores she receives and thus with the size of the male, probably owing to a larger content of spermatozoa in larger spermatophores. Because sperm are small and typically produced in very large numbers compared with eggs, sperm are traditionally considered an unlimited resource, but such observations suggest that sperm can be limiting. Dewsbury (1982) pointed out that sperm delivered to females in ejaculates or spermatophores, as in copepods, may be costly or slow to produce, and there is growing evidence to indicate that sperm supply can limit fertilization success and realized fecundity (Wedell et al. 2002). Spermatophore production may involve significant energetic investments for male copepods (Mauchline 1998), but the contents of sperm and semen in spermatophores is unknown in copepods. Copepod spermatophores contain various sub- stances besides spermatozoa (Defaye et al. 2000); if such substances are nutritional, large spermatophores may increase the female's fecundity, as found in other taxa such as insects. Female copepods may therefore have an advantage in mating with large young males, because (1) it reduces her need for frequent mating and thus reduces the potential risks of mating and (2) she receives sperm of high quality and quantity, which gives her a higher reproductive success. In this study we tested the hypothesis that size and age are significant factors influencing male fecundity (mating rate and sperm production) and reproductive fitness in the pelagic copepod, Temora longicornis.

\section{MATERIALS AND METHODS}

\section{Experimental copepods and general procedures}

Experiments were conducted with the calanoid copepod Temora longicornis, which was originally obtained from the central North Sea but has been cultured in our laboratory for over a year. Cultured $T$. longicornis decrease in size during subsequent generations (Klein-Breteler \& Gonzalez 1982). The culture was maintained and all experiments were conducted with food provided in excess, in darkness, at $14^{\circ} \mathrm{C}$ and at a salinity of 32 . Temperature and salinity were within the range in which the species thrives optimally (Maps et al. 2005). T. longicornis is a broadcast spawner and both the female and male engage in multiple matings. The adults measure about $1 \mathrm{~mm}$ in cephalothorax length. Females have normally 1 to 3 attached spermatophores. In this paper, 'age' refers to age since maturation; this is closely related to absolute age because maturation age varies very little for individuals grown under standardized conditions.

Most experiments (Expts 1 to 4 ) were conducted with virgin adults. To make sure that the copepods were virgins, late copepodites (Stages CIV to CV) were incubated individually in $69 \mathrm{ml}$ bottles. The bottles were inspected daily to obtain freshly moulted virgin adults. Copepods were incubated with food provided in excess $\left(1000 \mu \mathrm{g} \mathrm{C}^{-1}\right.$, phytoplankton of species Rhodomonas salina and Prorocentrum minimum). Copepods in Expt 1 were incubated in $69 \mathrm{ml}$ bottles and those in Expts 2 to 4 were incubated in $630 \mathrm{ml}$ screw-cap bottles. All bottles were sealed without a head space and placed on a plankton wheel that rotated at $1 \mathrm{rpm}$. 


\section{Expt 1: longevity of adult females and males}

Four males or females that had matured within $24 \mathrm{~h}$ were placed in each experimental bottle, 75 bottles for each sex. Every second day the numbers of live copepods were counted, dead ones were removed, and new food and water was added. The experiment continued until all copepods had died. The average duration of adult life was computed as the averages of the individual death dates (with $t_{0}=$ maturation date).

\section{Expt 2: duration of the fertile period of females, lifetime egg production and age-dependent egg production rate}

One virgin female and one virgin male were placed in each experimental bottle $(\mathrm{N}=10)$. After $24 \mathrm{~h}$, the female was isolated and her egg production monitored daily until she did not produce eggs for 4 consecutive days. Every day the female was transferred to a new bottle, the remaining water was filtered and the eggs were counted. The experiment was repeated using a slightly modified design to ensure that the females were unlimited by mating opportunities and sperm: The virgin females $(\mathrm{N}=10)$ were offered 3 males (to prevent mating and sperm limitation) and the males were replaced every $48 \mathrm{~h}$ throughout the experiment. Female egg production was monitored as above.

\section{Expt 3: age- and size-dependent male mating performance and fertility}

To estimate mating performance of males (quantified as the fraction of mating opportunities actually used) as a function of their age and size, 1 virgin male and 2 virgin females were placed in each of the 10 experimental bottles. Every $24 \mathrm{~h}$ the females were replaced with 2 new virgin females that had matured within $24 \mathrm{~h}$. The old females were transferred individually to a new experimental bottle containing seawater and food in excess, and their nauplii production was followed daily for $10 \mathrm{~d}$ to determine whether the female had been fertilized and to estimate the effect of male size on the total number of nauplii that a female could produce after 1 mating. Each male was offered a total of 20 females over a period of $10 \mathrm{~d}$. The size of the male was measured under a dissecting microscope.

\section{Expt 4: size of the spermatophore}

To examine the size of the spermatophore relative to the size of the male, virgin couples were incubated for $24 \mathrm{~h}(\mathrm{~N}=115)$. Each female was then inspected for attached spermatophores and the water was screened for lost spermatophores by means of a dissecting microscope. The sizes of the males and of the retrieved spermatophores were measured. Images were obtained with a digital video camera (uEye, Imaging Development Systems) connected to an inverted microscope (Olympus IX71), and analyzed with the shareware Image J 1.38X. We estimated the volume of each spermatophore from its length and width assuming an ellipsoid shape.

\section{Expt 5: sperm content in relation to spermatophore size}

The final experiment was designed to estimate the total number of spermatozoa inside the spermatophores of Temora longicornis. We retrieved spermatophores attached to females and used either females from our lab culture $(\mathrm{N}=30)$ or live females collected in the central and southern part of the North Sea in August 2010 ( $N=9$ ). To be sure that the spermatophores had not started emptying their contents, only female copepods with more than 2 attached spermatophores were used. The females have 2 genital openings, and it is believed that additional spermatophores cannot be connected to the genital openings because they are full. We modified existing DAPI protocols used for insects, bacteria and blue-green algae to stain the spermatozoa before counting (Porter \& Feig 1980, LaMunyon 2001). The females were killed by freezing at $-18^{\circ} \mathrm{C}$. After thawing, the females were rinsed in a phosphate buffer solution (PBS, pH 7.0) and individually transferred to a microscope slide. The spermatophores not attached directly to the genital pore were separated from the female by means of fine forceps, measured, and individually placed in a $30 \mu \mathrm{l}$ drop of PBS on a new microscope slide. The spermatophore was cut open with fine forceps to release the spermatozoa and the entire contents on the slide were transferred to a $1.5 \mathrm{ml}$ centrifuge tube. The microscope slide was rinsed several times in PBS to ensure that the entire contents were transferred. The sample was diluted with PBS to $187.5 \mu \mathrm{l}$ and centrifuged for $2 \mathrm{~min}$ at $2500 \mathrm{rpm}$ to separate the sperm from the spermatophore. The sample was then diluted to a total volume of $200 \mu \mathrm{l}$ with the addition of the DNA label 
4,6-diamidino-2-phenylindole (DAPI; final concentration $10 \mu \mathrm{g} \mathrm{ml}^{-1}$ ). Each sample was vortexed for $10 \mathrm{~s}$ and stored in the dark for at least 4 min to allow sufficient DAPI labelling. The stained sample was filtered through a $0.2 \mu \mathrm{m}$ black polycarbonate filter and the number of spermatozoa was counted under an epifluorescence microscope (Olympus; wave length, $365 \mathrm{~nm})$.

\section{RESULTS}

\section{Longevity and age-dependent mortality}

The adult longevity (mean $\pm \mathrm{SD}$ ) of virgin Temora longicornis was very similar between the 2 genders (females: $30.6 \pm 13.4 \mathrm{~d}$; males: $30.6 \pm 14.6 \mathrm{~d}$ ), as were the temporal patterns of survivorship and mortality

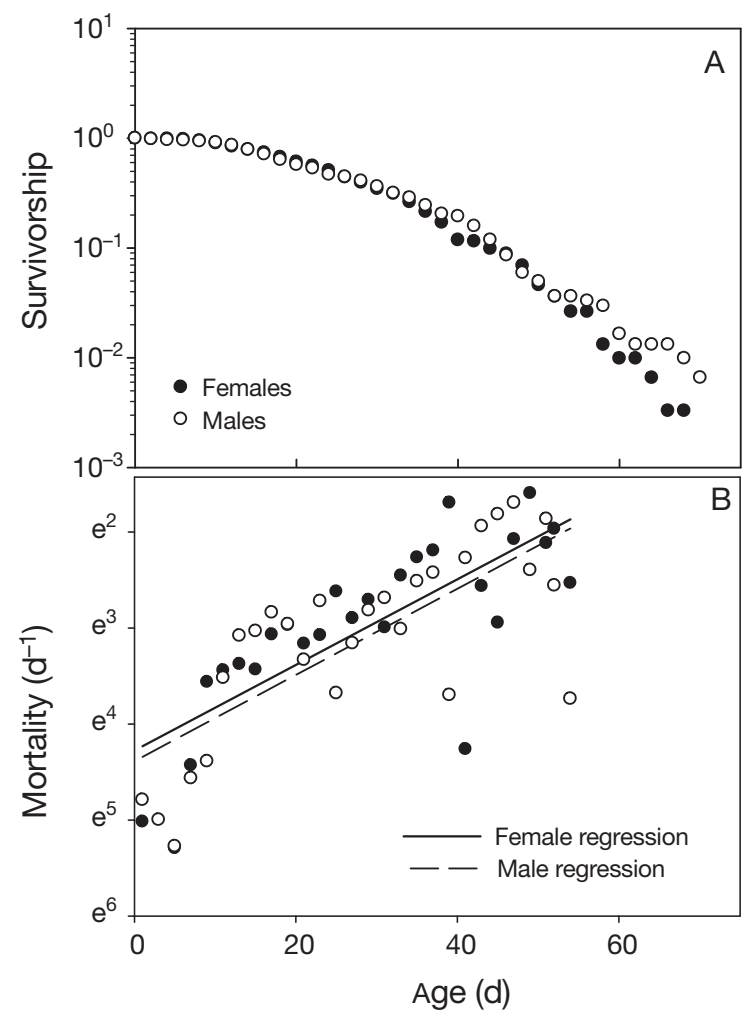

Fig. 1. Temora longicornis. (A) Survivorship curves for virgin females $(\bullet N=300)$ and virgin males $(0 ; N=300)$. Survivorship is defined as the fraction of individuals surviving as a function of time. (B) Instantaneous mortality rates of males and females computed for $2 \mathrm{~d}$ intervals as long as there were at least 10 individuals left in the cohort. Female regression: $\log _{\mathrm{e}}\left[\right.$ mortality $\left.\left(\mathrm{d}^{-1}\right)\right]=-4.28+0.045 \cdot[$ age $(\mathrm{d})]\left(\mathrm{R}^{2}=0.58\right)$; male regression: $\log _{e}\left[\right.$ mortality $\left.\left(\mathrm{d}^{-1}\right)\right]=-4.39+0.045 \cdot[$ age $(\mathrm{d})]$ $\left(\mathrm{R}^{2}=0.57\right)$. Both relations are statistically significant $(\mathrm{p}<$ 0.001) whereas the difference between male and female mortality patterns is not

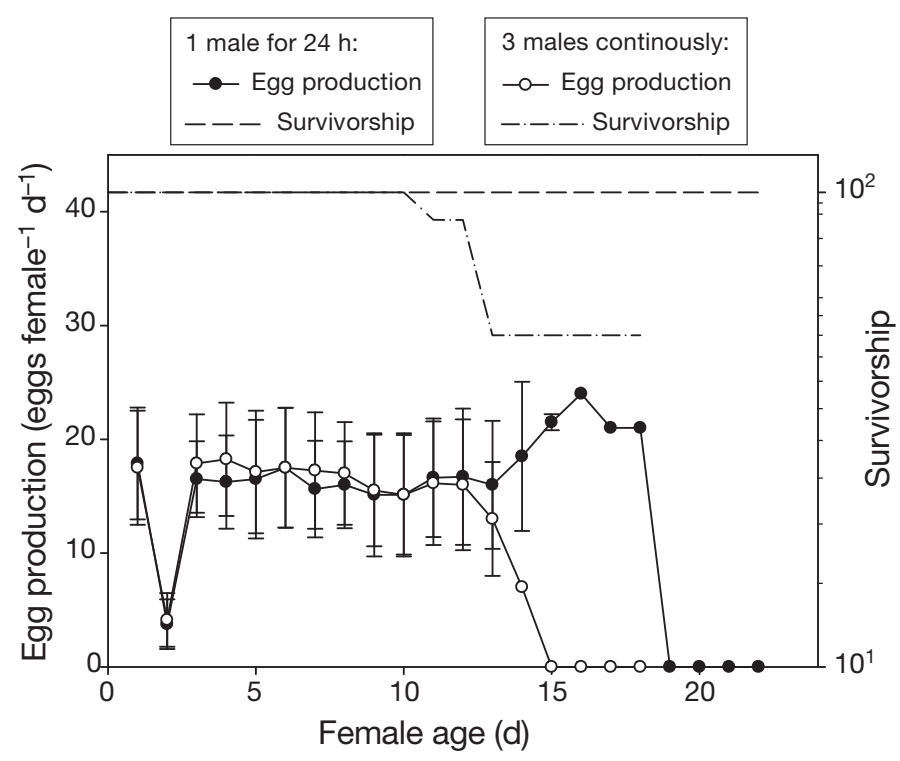

Fig. 2. Temora longicornis. Egg production rate (no. eggs female ${ }^{-1} d^{-1}$; means \pm SD) as a function of female age (d) since maturation, for females incubated with a single male for $24 \mathrm{~h}(\bullet)$ and for females continuously incubated with 3 males (O) ( $\mathrm{N}=8$ for each treatment). The experiment was run until the females did not produce eggs for 4 consecutive days (zero values). Only females producing eggs were included ( $20 \%$ of the females never produced eggs). Survivorship curves (dashed lines) during the experiment are significantly different for females with 1 male or 3 males (Mann-Whitney rank sum, $\mathrm{p}=0.001$ )

rates (Fig. 1). The maximum individual lifespan observed among the 300 individuals of the 2 genders was 68 and $70 \mathrm{~d}$ for females and males, respectively. The mortality rates increased significantly with age and led to a concave shape of the log survival versus age curves (Fig. 1); hence, both male and female age and ageing become evident in the curves as elevated mortality for both genders.

\section{Duration of the fertile period of females, and age-dependent and lifetime egg production}

The fertile period of the female was short relative to the average longevity (cf. above) and varied only insignificantly between the 2 treatments, $13.9 \pm 2.0 \mathrm{~d}$ for females incubated with a single male for $24 \mathrm{~h}$ and $12.3 \pm 1.2 \mathrm{~d}$ for females incubated with males throughout the reproductive period (Fig. 2 ) ( $t$-test, $\mathrm{p}=$ 0.070 ). The lifetime egg production was also similar between the 2 treatments $(218 \pm 76$ vs. $191 \pm 41$ eggs, $p=0.388$ ), which suggested that cessation of egg production was not due to a shortage of sperm. In both 
treatments, $20 \%$ of the females did not produce any eggs during the experiment and therefore they are not included in the results. Repeated mating led to a higher mortality in females (Fig. 2).

\section{Age-dependent male mating performance and fertility}

Males mated only during the first $8 \mathrm{~d}$ after they matured, and the decline in mating performance had already started after $5 \mathrm{~d}$ (Fig. 3A). Again, this fertile period is short relative to the average longevity of males (cf. above). Also, the female's offspring production is related to the age of the male with which she had mated: young fathers sire significantly more offspring per mating than do older ones (Fig. 3B). The size of the female will also affect her offspring production (cf. below), which thus accounts for the large variance in offspring production, but all females in this experiment were virgins and of the same age (matured within $24 \mathrm{~h}$ ). Therefore, the general decrease in offspring production is a result of the age of the male.

\section{Size-dependent male mating performance and fertility}

Large males were superior to small males in terms of reproductive performance in 2 ways: large males both mated more frequently (Fig. 4A) and sired more offspring per successful mating than small males (Fig. 4B).

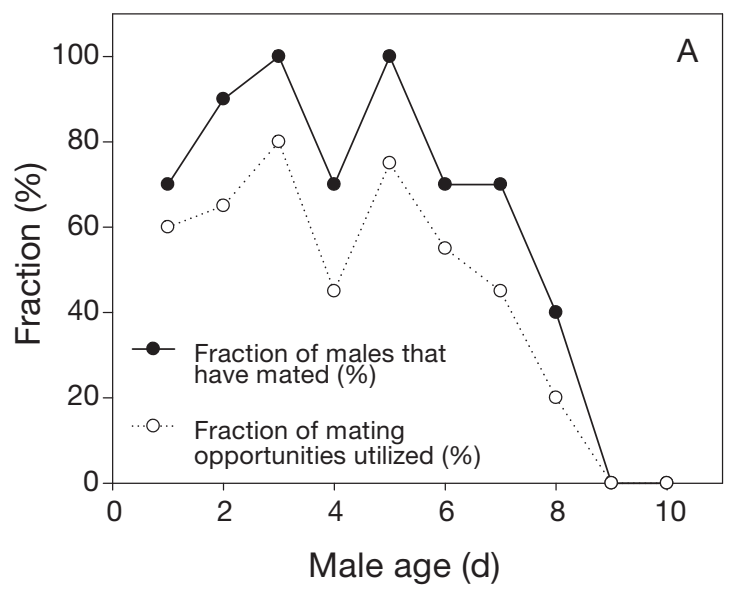

\section{Size-dependent female reproduction}

To examine whether the size of the female has an effect on total lifetime offspring production and egg production rate, data for all females were compiled. Large females had a higher total lifetime offspring production compared with small females and they also had a higher instantaneous egg production rate (Fig. 5). The size effect was substantial: a $30 \%$ increase in female body length led to a 2- to 3-fold increase in egg production, which suggests that the egg production is approximately proportional to female body volume.

\section{Spermatophore size and sperm content}

Male size and spermatophore size varied substantially, and large males produced larger spermatophores than did small males (Fig. 6A). In fact, a modest increase in male prosome length (750 to $780 \mu \mathrm{m})$ led to a 4 -fold increase in spermatophore volume. Larger spermatophores contained more sperm cells, although sperm content was far from proportional to spermatophore volume (a 4-fold increase in volume led to an increase in sperm count from 1000 to 1300) (Fig. 6B). This modest increase in spermatozoa number with increased volume suggested that large spermatophores either have a disproportionally larger swelling capacity to create hydrostatic pressure for sperm transferral or contain disproportional amounts of additional substances that are transferred with the sperm. The average number of spermatozoa inside a

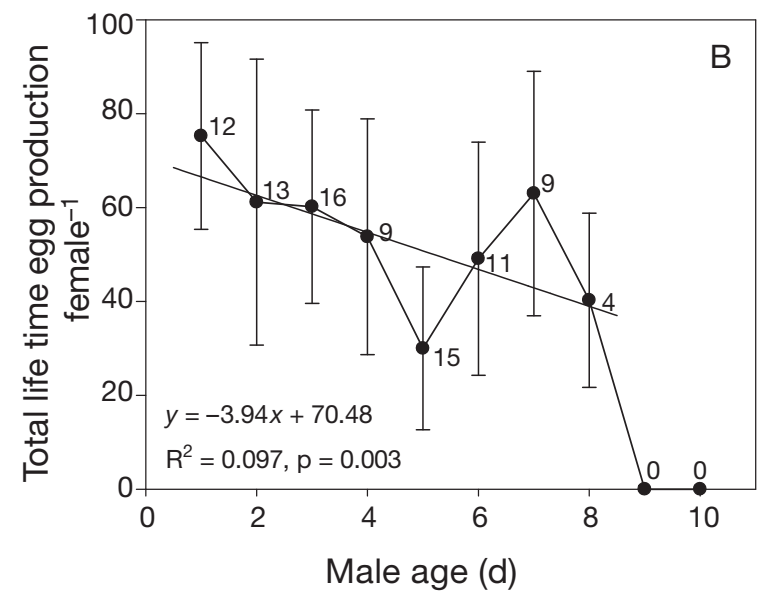

Fig. 3. Temora longicornis. Male mating performance and fertility. (A) The fraction of males (out of 10 males) that had mated as a function of male age since maturation (•) and the fraction of mating opportunities used (fraction of 20 females fertilized) as a function of male age (O). (B) Total life time offspring production per fertilized female \pm SD as a function of male age since maturation (d). The numbers correspond to the number of fertilized females out of 20. The trend line is a linear regression that used individual values (not averages) for Days 1 to 8 ; the slope of this regression is statistically significant ( $p=0.003$ ) and demonstrates that young males sire more offspring per mating than do old males in the reproductive period 

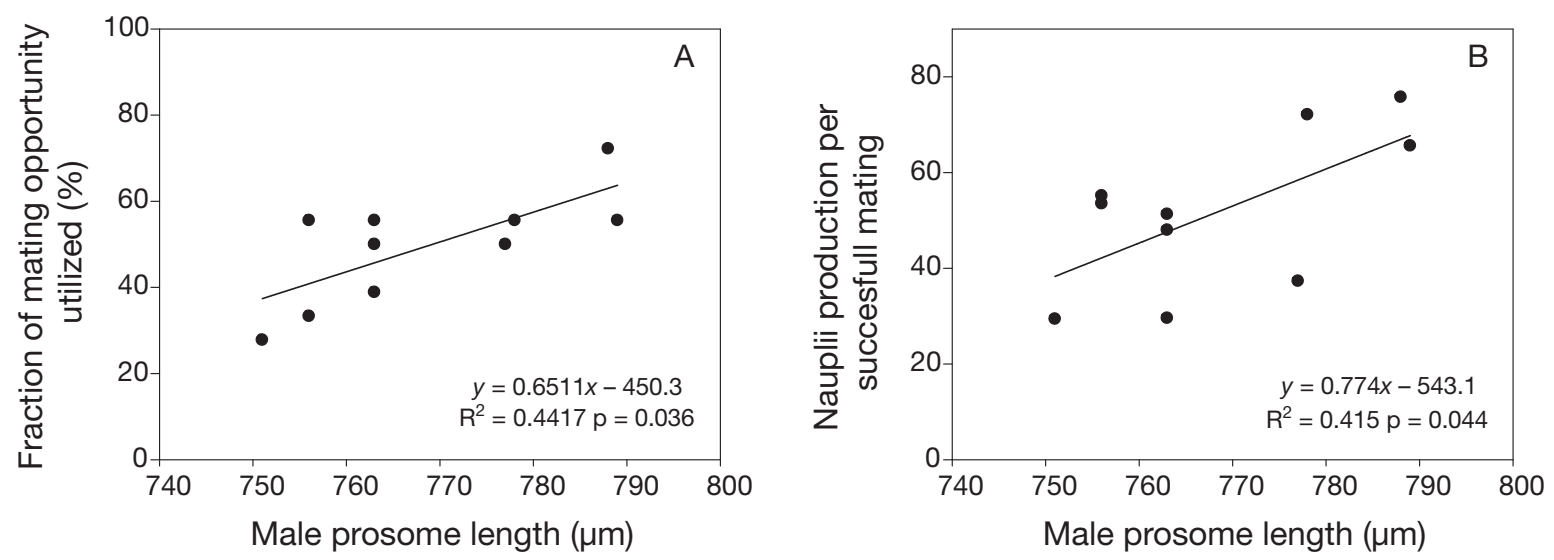

Fig. 4. Temora longicornis. (A) Fraction of mating opportunities that males had used (\%) as a function of male size. (B) Nauplii production per successful mating as a function of the father's size. The experiment lasted $8 \mathrm{~d}$ and each male ( $\mathrm{N}=10) \mathrm{was}$ offered 2 new virgin females every day. Same experimental individuals as in Fig. 3
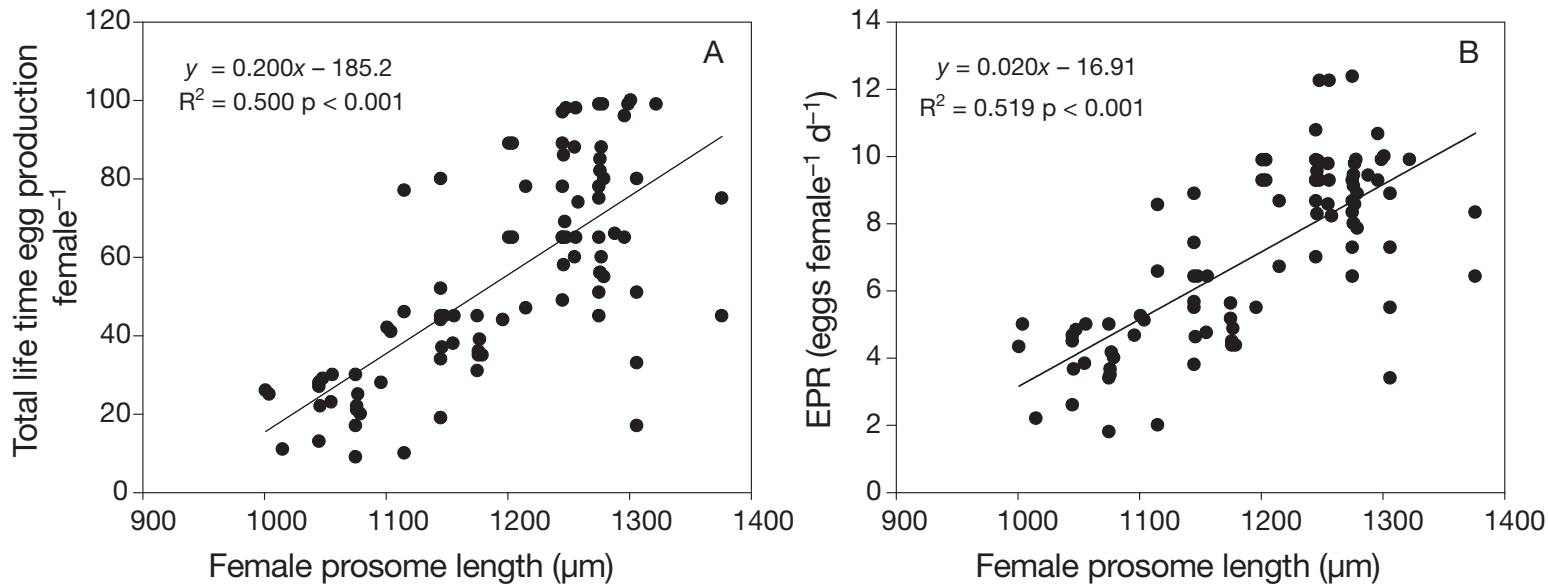

Fig. 5. Temora longicornis. (A) Lifetime egg production as a function of the female prosome size ( $\mathrm{N}=89$ ). (B) Egg production rate $(\mathrm{EPR})$ as a function of female prosome length. The egg production was followed for $10 \mathrm{~d}$
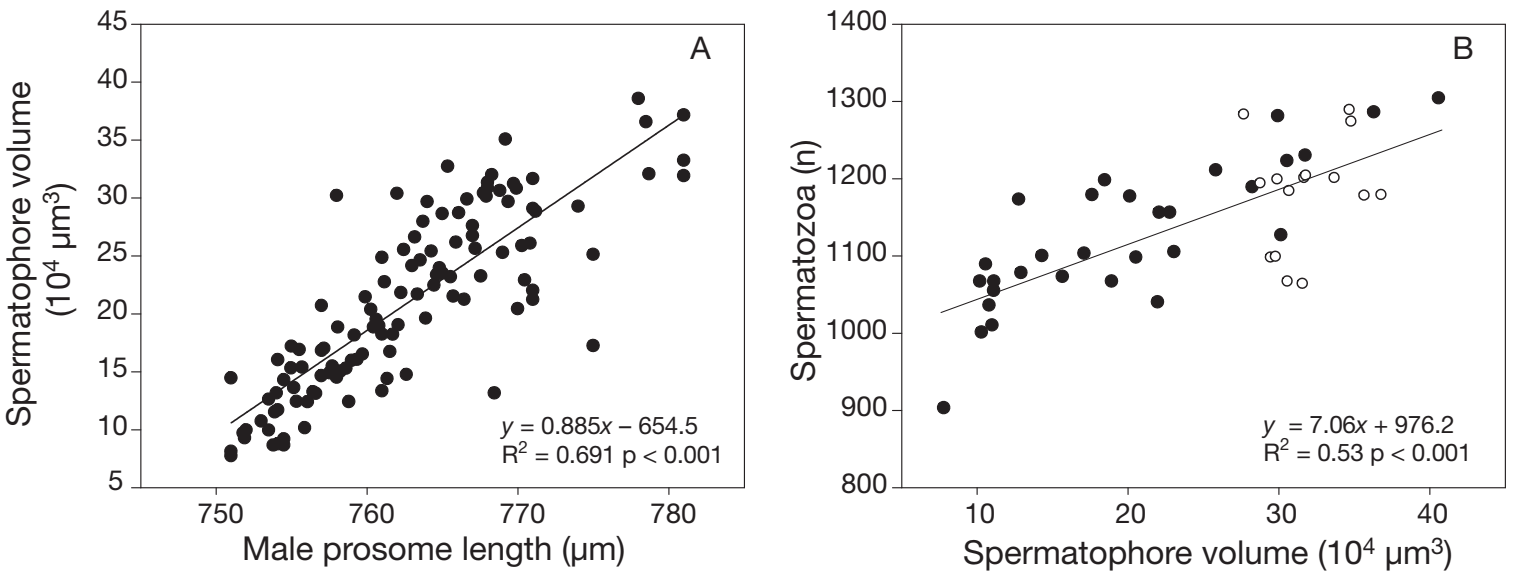

Fig. 6. Temora longicornis. (A) Spermatophore volume $\left(10^{4} \mu \mathrm{m}^{3}\right)$ as a function of male size $(\mu \mathrm{m})(\mathrm{N}=115)$. (B) Number of spermatozoa as a function of the spermatophore volume $\left(10^{4} \mu \mathrm{m}^{3}\right)$ in a laboratory culture $(\bullet)(\mathrm{N}=30)$ and in field samples $(\mathrm{O})$ $(\mathrm{N}=15)$ 
single spermatophore was $1126 \pm 92$, which corresponds to about 5 times the number of eggs that a female can produce after a mating event.

\section{DISCUSSION}

Our results showed 3 clear findings. (1) Ageing effects were evident. Mortality rate increased with age, and fertility decreased rapidly with age. This latter effect was stronger in males than females. Also, in both genders, the reproductive period was significantly shorter than the average longevity. (2) Several aspects of reproductive performance increased with size in both males and females: large females produced more offspring than small ones, and large males mated more often, produced larger spermatophores containing more sperm cells and sired more offspring. (3) Repeated mating was not only potentially advantageous (e.g. in terms of higher genetic variability) for females, but could also have had disadvantages as it led to higher mortality. While the absolute rates and durations reported in this study applied to our laboratory culture and conditions of the experiments, we believe that the patterns apply generally to this species.

Young males of Temora longicornis have a higher mating success and a higher reproductive success compared with old males. Whether this is due to females preferring young males, young males performing better (better sperm quality and quantity) or young males being more efficient in capturing and mating with females is unknown. In theory, female preference for males of particular ages is thought to be maintained largely through the benefits accrued by choosy females (Manning 1985, Hansen \& Price 1995, Kokko 1998, Beck \& Powell 2000, Proulx et al. 2002). One possible explanation for the elevated offspring production in young males is declining sperm number in old males, or increasing damage to the DNA or the spermatozoan cell membrane as seen in other species (Vishwanath \& Shannon 1997, Irvine et al. 2000). Theory predicts that sperm quality declines with age owing to the accumulation of de novo mutations in the germline cells (Hansen \& Price 1995, 1999). Females mating with old males may therefore suffer reduced fertility. Sperm age may be independent of male age; successful males may replenish their sperm frequently and so have better fertilization success than less successful competitors regardless of age (Siva-Jothy 2000). The old males in this experiment were not virgins and were offered new females daily. Therefore, the possibility is low that their sperm is old, and the observed decline in male success with age is probably an effect of male age. Direct trade-offs between fitness components and age-specific differences in survival may reduce the fertility of older males and instead promote the evolution of female preference for young males and those of intermediate age (Hansen \& Price 1995, 1999, Kokko 1997, Beck \& Powell 2000, Beck et al. 2002). Males in particular, but also females, can survive beyond their reproductive time period (30.6 versus 8 or 15 d). Such post-reproductive life may be an evolutionary adaptation to low mate-encounter rates if the reproductive performance is maintained in the absence of matings, as shown in another pelagic copepod species (Ceballos \& Kiørboe 2011).

Size is a heritable trait in copepods (McLaren 1976, McLaren \& Corkett 1978) and females that choose large males may therefore sire larger sons and daughters that likewise sire more offspring (Weatherhead \& Robertson 1979). Morphologically, body size is positively correlated with reproductive organ size and total number of gametes, and it is well documented in comparisons between species that egg production rates in copepods, like in many other organisms, increase with size (Kiørboe \& Hirst 2008). Comparisons within species are rare and the relationship observed here for Temora longicornis is much more pronounced than comparisons between species, where numerical egg production increases with body mass (or volume) to a power of 0.2 (Kiørboe \& Hirst 2008). The size dependency of reproductive performance in male copepods has previously been examined in only one other species, Acartia tonsa (Ceballos \& Kiørboe 2010), and is in accordance with our observation in $T$. longicornis that large males produce larger spermatophores and sire more offspring per mating than do small males. We showed that this is related to a higher content of sperm cells in the spermatophores.

Multiple mating (polyandry) in female insects is reported to increase fecundity and egg viability across a range of taxa (Arnqvist \& Nilsson 2000). In copepods, polyandry is often observed both in laboratory and field populations (many attached spermatophores), and it is typically assumed that copepods belonging to the superfamily Centropagoidea, such as Temora longicornis, need to mate several times during their life because they lack dedicated sperm storage organs (spermathecae). This is, for example, the case in a sibling species, T. stylifera (Barthélémy et al. 1998). However, a female of T. longicornis receives sufficient sperm in 1 mating to fertilize all the eggs she produces in her life. In our 
study, the lifetime egg production was $203 \pm 62$ eggs and the number of sperm per spermatophore ranged from 900 to 1300 . This means that the female only use 15 to $22 \%$ of the sperm in 1 spermatophore to fertilize all of her eggs. Consistent with this, we find that multiple matings in $T$. longicornis do not increase the reproductive output in the females. We did not examine whether the offspring from one or several mating opportunities had different fitness levels, e.g. in terms of higher survival, and whether multiple mating secures higher genetic variation or allows for cryptic mate choice leading to fitter offspring. It is unclear whether cryptic mate choice is at all feasible in copepods because the genital opening may be blocked by the spermatophore or in some species by a cement plug, but there is molecular evidence in one such species, Lepeophtheirus salmonis, that a batch of eggs may in fact be sired by several fathers (Todd et al. 2005). However, there is a mortality penalty related to matings; repeated mating leads to a higher mortality in females (Fig. 2), probably owing to elevated energy consumption or damage or injury by the male when mating. This has also been demonstrated for another copepod species (Oithona davisae; Ceballos \& Kiørboe 2011) and in several insect species (Campbell 2005, Wenninger \& Hall 2008); thus, any advantages of multiple matings have to be traded off against the mortality penalty. In some species of insects, the seminal fluid contains substances that increase the male's relative paternity at the expense of female fitness (Chapman et al. 1995, Simmons 2001, Gillott 2003), which explains the elevated mortality of females that mate multiple times (Arnqvist \& Nilsson 2000). The volume of the spermatophores and the volume of the total number of spermatozoa leave plenty of space in the spermatophores for seminal fluids.

Titelman et al. (2007) reviewed indirect evidence to suggest that mating in pelagic copepods was nonrandom and the result of mate choice. The strong ageand size-dependency of the reproductive output in both males and females and the mortality penalty to mating, in at least the females, are conducive to the development of sexual selection through mate choosiness. Necessary conditions for the development of choosiness are a high mate encounter rate, a cost to mating (in terms of elevated mortality or lost future mating opportunities) and, finally, that mates are of different quality and being choosy implies a fitness benefit (Kokko \& Monaghan 2001, Shuster 2007). We have shown for Temora longicornis that mating with large, young partners implies higher offspring production in both males and females, and have provided evidence (higher mating success of young, large males) that is consistent with mate choosiness. Our study, together with recent observations of sexual selection through mate choosiness in other species of copepods (Ceballos \& Kiørboe 2010), adds further evidence that sexual selection is an important determinant of the behavioral ecology and population dynamics of pelagic copepods.

Acknowledgements. The project was supported by a grant to the research school SLIP from the Danish Agency for Science Technology and Innovation (grant no. 645-09-0040) to M.H.S. and a grant from the Danish Council for Independent Research to T.K. We thank S. Ceballos, Technical University of Denmark, for her precious advice during the study and for help and guidance in the laboratory, and J. Heuschele, Technical University of Denmark, for his comments and insights.

\section{LITERATURE CITED}

Andersson MB (1994) Sexual selection. Princeton University Press, Princeton, NJ

Aquiloni L, Gherardi F (2008) Mutual mate choice in crayfish: large body size is selected by both sexes, virginity by males only. J Zool 274:171-179

Arendt KE, Jonasdottir SH, Hansen PJ, Gartner S (2005) Effects of dietary fatty acids on the reproductive success of the calanoid copepod Temora longicornis. Mar Biol 146:513-530

Arnqvist G, Nilsson T (2000) The evolution of polyandry: multiple mating and female fitness in insects. Anim Behav 60:145-164

- Ban SH (1994) Effect of temperature and food concentration on postembryonic development, egg production and adult body size of calanoid copepod Eurytemora affinis. J Plankton Res 16:721-735

Barthélémy RM, Cuoc C, Defaye D, Brunet M, Mazza J (1998) Female genital structures in several families of Centropagoidea (Copepoda: Calanoida). Philos Trans R Soc Lond B Biol Sci 353:721-736

> Bartosch-Härlid A, Berlin S, Smith NGC, Moller AP, Ellegren $\mathrm{H}$ (2003) Life history and the male mutation bias. Evolution 57:2398-2406

Beck CW, Powell LA (2000) Evolution of female mate choice based on male age: Are older males better mates? Evol Ecol Res 2:107-118

Beck CW, Shapiro B, Choksi S, Promislow DEL (2002) A genetic algorithm approach to study the evolution of female preference based on male age. Evol Ecol Res 4: 275-292

> Berggreen U, Hansen B, Kiørboe T (1988) Food size spectra ingestion and growth of the copepod Acartia tonsa during development: implications for determination of copepod production. Mar Biol 99:341-352

Bissoondath CJ, Wiklund C (1996) Effect of male mating history and body size on ejaculate size and quality in two polyandrous butterflies, Pieris napi and Pieris rapae (Lepidoptera: Pieridae). Funct Ecol 10:457-464

> Brooks R, Kemp DJ (2001) Can older males deliver the good genes? Trends Ecol Evol 16:308-313

Campbell JF (2005) Fitness consequences of multiple mat- 
ing on female Sitophilus oryzae L. (Coleoptera: Curculionidae). Environ Entomol 34:833-843

- Carlotti F, Rey C, Javanshir A, Nival S (1997) Laboratory studies on egg and faecal pellet production of Centropages typicus: effect of age, effect of temperature, individual variability. J Plankton Res 19:1143-1165

Ceballos S, Kiørboe T (2010) First evidences of sexual selection by mate choice in marine zooplankton. Oecologia 164:627-635

Ceballos S, Kiørboe T (2011) Senescence and sexual selection in a pelagic copepod. PLoS ONE 6:e18870

> Chapman T, Liddle LF, Kalb JM, Wolfner MF, Partridge L (1995) Cost of mating in Drosophila melanogaster females is mediated by male accessory gland products. Nature 373:241-244

> Dam HG, Lopes RM (2003) Omnivory in the calanoid copepod Temora longicornis: feeding, egg production and egg hatching rates. J Exp Mar Biol Ecol 292:119-137

Dam HG, Peterson WT (1991) In situ feeding behavior of the copepod Temora longicornis: effects of seasonal changes in chlorophyll size fractions and female size. Mar Ecol Prog Ser 71:113-123

> Defaye D, Cuoc C, Brunet M (2000) Genital structures and spermatophore placement in female Paradiaptominae (Copepoda, Calanoida, Diaptomidae). J Crustac Biol 20: 245-261

Dewsbury DA (1982) Ejaculate cost and male choice. Am Nat 119:601-610

Dewsbury DA (1982) Ejaculate cost and male choice. Am Nat 119:601-610

$>$ Drost JB, Lee WR (1995) Biological basis of germline mutation: comparisons of spontaneous germline mutation rates among drosophila, mouse, and human. Environ Mol Mutagen 25:48-64

Gasparini C, Marino IAM, Boschetto C, Pilastro A (2010) Effect of male age on sperm traits and sperm competition success in the guppy (Poecilia reticulata). J Evol Biol 23: $124-135$

Gillott C (2003) Male accessory gland secretions: modulators of female reproductive physiology and behavior. Annu Rev Entomol 48:163-184

Glaser RL, Jabs EW (2004) Dear old dad. Sci Aging Knowl Environ 2004:re1 doi:10.1126/sageke.2004.3.re1

Hansen TF, Price DK (1995) Good genes and old age: Do old mates provide superior genes? J Evol Biol 8:759-778

- Hansen TF, Price DK (1999) Age- and sex-distribution of the mutation load. Genetica 106:251-262

> Holste L, St. John MA, Peck MA (2009) The effects of temperature and salinity on reproductive success of Temora longicornis in the Baltic Sea: a copepod coping with a tough situation. Mar Biol 156:527-540

> Honêk A (1993) Intraspecific variation in body size and fecundity in insects: a general relationship. Oikos 66: 483-492

> Hurst LD, Ellegren H (1998) Sex biases in the mutation rate. Trends Genet 14:446-452

Irvine DS, Twigg JP, Gordon EL, Fulton N, Milne PA, Aitken RJ (2000) DNA integrity in human spermatozoa: relationships with semen quality. J Androl 21:33-44

> Jonasdottir SH, Fields D, Pantoja S (1995) Copepod egg production in Long Island Sound, USA, as a function of the chemical composition of seston. Mar Ecol Prog Ser 119: 87-98

> Jonasdottir SH, Visser AW, Jespersen C (2009) Assessing the role of food quality in the production and hatching of Temora longicornis eggs. Mar Ecol Prog Ser 382: $139-150$

Judge KA, Tran KC, Gwynne DT (2010) The relative effects of mating status and age on the mating behaviour of female field crickets. Can J Zool 88:219-223

Kiørboe T, Hirst AG (2008) Optimal development time in pelagic copepods. Mar Ecol Prog Ser 367:15-22

Klein-Breteler WCM, Gonzalez SR (1982) Influence of cultivation and food concentration on body length of calanoid copepods. Mar Biol 71:157-161

Kokko H (1997) Evolutionarily stable strategies of agedependent sexual advertisement. Behav Ecol Sociobiol 41:99-107

Kokko H (1998) Good genes, old age and life-history tradeoffs. Evol Ecol 12:739-750

Kokko H, Monaghan P (2001) Predicting the direction of sexual selection. Ecol Lett 4:159-165

> Koski M, Breteler WK, Schogt N, Gonzalez S, Jakobsen HH (2006) Life-stage-specific differences in exploitation of food mixtures: diet mixing enhances copepod egg production but not juvenile development. J Plankton Res 28: 919-936

LaMunyon CW (2001) Determinants of sperm precedence in a noctuid moth Heliothis virescens: a role for male age. Ecol Entomol 26:388-394

Lehmann GUC, Lehmann AW (2009) Condition-dependent spermatophore size is correlated with male's age in a bushcricket (Orthoptera: Phaneropteridae). Biol J Linn Soc 96:354-360

MacDiarmid AB, Butler MJ IV (1999) Sperm economy and limitation in spiny lobsters. Behav Ecol Sociobiol 46: $14-24$

> Manning JT (1985) Choosy females and correlates of male age. J Theor Biol 116:349-354

Maps F, Runge JA, Zakardjian B, Joly P (2005) Egg production and hatching success of Temora longicornis (Copepoda, Calanoida) in the southern Gulf of St. Lawrence. Mar Ecol Prog Ser 285:117-128

Mauchline J 1998. The biology of calanoid copepods. Academic Press, London

McLain DK, Lanier DL, Marsh NB (1990) Effects of female size, mate size, and number of copulations on fecundity, fertility, and longevity of Nezara viridula (Hemiptera, Pentatomidae). Ann Entomol Soc Am 83:1130-1136

> McLaren IA (1976) Inheritance of demographic and production parameters in marine copepod Eurytemora herdmani. Biol Bull (Woods Hole) 151:200-213

> McLaren IA, Corkett CJ (1978) Unusual genetic variation in body size, development times, oil storage, and survivorship in marine copepod Pseudocalanus. Biol Bull (Woods Hole) 155:347-359

Pizzari T, Dean R, Pacey A, Moore H, Bonsall MB (2008) The evolutionary ecology of pre- and post-meiotic sperm senescence. Trends Ecol Evol 23:131-140

Porter KG, Feig YS (1980) The use of DAPI for identifying and counting aquatic microflora. Limnol Oceanogr 25: 943-948

> Proulx SR, Day T, Rowe L (2002) Older males signal more reliably. Proc Biol Sci 269:2291-2299

> Radwan J (2003) Male age, germline mutations and the benefits of polyandry. Ecol Lett 6:581-586

Radwan J, Michalczyk L, Prokop Z (2005) Age dependence of male mating ability and sperm competition success in the bulb mite. Anim Behav 69:1101-1105

Risch N, Reich EW, Wishnick MM, McCarthy JG (1987) 
Spontaneous mutation and parental age in humans. Am J Hum Genet 41:218-248

Rodriguez-Grana L, Calliari D, Tiselius P, Hansen BW, Skold HN (2010) Gender-specific ageing and non-Mendelian inheritance of oxidative damage in marine copepods. Mar Ecol Prog Ser 401:1-13

Shuster SM (2007) The evolution of crustacean mating systems. In: Duffy JM, Thiel M (eds) Evolutionary ecology of social and sexual systems. Oxford University Press, Oxford, p 29-47

Simmons LW (2001) Sperm competition and its evolutionary consequences in insects. Princeton University Press, NJ

Siva-Jothy MT (2000) The young sperm gambit. Ecol Lett 3: 172-174

> Titelman J, Varpe O, Eliassen S, Fiksen O (2007) Copepod mating: chance or choice? J Plankton Res 29:1023-1030

Editorial responsibility: Edward Durbin,

Narragansett, Rhode Island, USA
Todd CD, Stevenson RJ, Reinardy H, Ritchie MG (2005) Polyandry in the ectoparasitic copepod Lepeophtheirus salmonis despite complex precopulatory and postcopulatory mate-guarding. Mar Ecol Prog Ser 303:225-234

Vishwanath R, Shannon P (1997) Do sperm cells age? A review of the physiological changes in sperm during storage at ambient temperature. Reprod Fertil Dev 9:321-331

Weatherhead PJ, Robertson RJ (1979) Offspring quality and the polygyny threshold: 'the sexy son hypothesis'. Am Nat 113:201-208

Wedell N, Gage MJG, Parker GA (2002) Sperm competition, male prudence and sperm-limited females. Trends Ecol Evol 17:313-320

Wenninger EJ, Hall DG (2008) Importance of multiple mating to female reproductive output in Diaphorina citri. Physiol Entomol 33:316-321

Submitted: March 7, 2011; Accepted: September 15, 2011 Proofs received from author(s): November 27, 2011 